\title{
Carbon Mineralization of Agro-Food Waste Compost in Soil under Controlled Conditions
}

\author{
SANONKA TCHEGUENI ${ }^{1 *}$, MAGNOUDÉWA B. BODJONA ${ }^{1}$, \\ KOKOU SABI ${ }^{2}$ and MOURSALOU KORIKO ${ }^{1}$
}

\author{
${ }^{1}$ Laboratoire Gestion, Traitement et Valorisation des Déchets (GTVD), Faculté Des Sciences, \\ Université de Lomé, BP 1515 Lomé-Togo. \\ ${ }^{2}$ Laboratoire de Chimie Atmosphérique (LCA), Faculté Des Sciences, Université de Lomé, \\ BP 1515 Lomé-Togo. \\ *Corresponding author E-mail: tchegsani@gmail.com \\ http://dx.doi.org/10.13005/ojc/340321
}

(Received: November 17, 2017; Accepted: February 07, 2018)

\begin{abstract}
Compost mineralization study under controlled conditions is a way to predict the compost behavior in the soil. It permits to know how much compost to bring to the soil to ensure a good amendment and how long the compost will last in the soil. Six composts obtained from agro-food waste are incubated under controlled conditions in order to follow the carbon mineralization. Soil-compost mixtures (100:1) are incubated at $2 / 3$ of soil moisture capacity for 75 days and under ambient temperature $\left(30^{\circ} \mathrm{C}\right)$. The soil-compost mixtures released and during 75 days and 15.96 to $27.52 \mathrm{mg}$ of $\mathrm{C}-\mathrm{CO}_{2}$, versus $4.89 \mathrm{mg}$ for the control without compost. This correspond to the carbon potentially mineralizable varing between 25 and $46 \%$ of the total organic carbon. The pH of composts and their $\mathrm{C} / \mathrm{N}$ ratio have effected carbon mineralization.
\end{abstract}

Keywords: Compost, Organic carbon, Mineralization, Soil.

\section{INTRODUCTION}

Compost is an organic amendment that improves the physical and chemical properties of the soil ${ }^{1}$ and increases soil biodiversity, because of its microbial flora ${ }^{2}$. Despite these beneficial effects of compost, its use under certain conditions can pose some problems to the soil-plant system.

The mineralization of organic matter in the soil leads to its degradation under favorable conditions of temperature, humidity and $\mathrm{pH}$ resulting in the release of minerals $\left(\mathrm{NH}_{4}^{+}, \mathrm{K}^{+} \mathrm{Ca}^{2+}, \mathrm{Mg}^{2+}\right)$ essential plants. The study of the mineralization of the compost in the controlled conditions can predict the behavior of the compost in the soil, the quantity useful to a good amendment and the duration of its effect in the soil.

Incubation of compost under controlled conditions and field trial are two complementary methods of studying the effects of compost in the soil 
often used. In controlled conditions, the incubation consists in mixing the compost with a soil of known characteristics, in a closed enclosure (generally a jar) so as to follow the mineralization of carbon or organic nitrogen. The jars thus formed are kept in the dark and under precise temperature and humidity conditions for a variable duration. Many temperatures are used by authors, $25{ }^{\circ} \mathrm{C}$ by Huang ${ }^{3}$, and $30{ }^{\circ} \mathrm{C}$ by Cambardella ${ }^{4}$. Moisture content varies between $50 \%$ and $75 \%$ of soil water holding capacity $1,5,6$.

Incubation in controlled conditions can be a modeling prior to spreading over larger areas. Mathematical models are used to describe the kinetics of carbon mineralization during incubation?. As for the field trial, it allows to know the influence of a contribution of organic matter in the form of compost on the structure of a soil.

This work aims to determine the labile fractions of organic matter and the degradation rates of six compost made from agro-food waste.

\section{MATERIAL AND METHODS}

\section{Material}

Composts used, obtained from the composting of agro-food waste, were characterized using the parameters mentioned in Table 1.

The soil used for this study is taken from the agro-educational farm in the Agronomy school of the University of Lome (Table 2).

\section{Methods}

$25 \mathrm{~g}$ of dry soil and $0.25 \mathrm{~g}$ of compost were mixed and placed in $75 \mathrm{ml}$ flasks at a humidity adjusted to about $2 / 3$ of the field capacity ${ }^{8}$. Then,
Table 2: Physico-chemical characteristics of the soil

\begin{tabular}{lc}
\hline Parameter & Value \\
& \\
$\mathrm{pH}$ & $7.73 \pm 0.24$ \\
$\mathrm{TOC}(\%)$ & $0.60 \pm 0.07$ \\
$\mathrm{P}$ assimilable $(\mathrm{mg} / \mathrm{kg})$ & $13.02 \pm 0.99$ \\
Exchangeable cations $(\mathrm{mg} / \mathrm{kg})$ & \\
$\mathrm{Ca}$ & $336.25 \pm 16.17$ \\
$\mathrm{Mg}$ & $27.20 \pm 5.50$ \\
$\mathrm{~K}$ & $35.20 \pm 2.41$ \\
$\mathrm{CEC}(\mathrm{cmol}+\mathrm{kg})$ & $1.80 \pm 0.09$ \\
Granulometry $(\%)$ & \\
Coarse sand & 60.45 \\
Fine sand & 25.15 \\
Coarse silt & 2.75 \\
Fine silt & 3.00 \\
Clay & 7.00 \\
\hline
\end{tabular}

the flasks were placed in $500 \mathrm{ml}$ sealed enclosures. Two vials of $20 \mathrm{ml}$ were placed inside each chamber, one containing $10 \mathrm{ml}$ of deionized water to saturate the atmosphere with water, and the other containing $10 \mathrm{ml}$ of sodium hydroxide $1 \mathrm{~N}$ solution, to fix the $\mathrm{CO}_{2}$ released by the mineralization ${ }^{9}$. The whole is kept at room temperature $\left(30^{\circ} \mathrm{C}\right)$. All treatments were in three replicates.

At fixed time intervals, the chambers are opened to renew the oxygen while the bottles containing sodium hydroxide $1 \mathrm{~N}$ solution were removed to be replaced by solution. The $\mathrm{CO}_{2}$ released by the mineralization and captured by the sodium hydroxide $1 \mathrm{~N}$ solution is precipitated by $5 \mathrm{ml}$ $5 \% \mathrm{BaCl}_{2}$. The amount of sodium hydroxide remaining in the solution is titrated with $0.1 \mathrm{~N}$ hydrochloric acid

Table 1: Characteristics of composts

\begin{tabular}{llccccc}
\hline & Basic material & pH & OM (\%) & TOC (\%) & NTK (\%) & C/N \\
\hline Compost $A_{0}$ & Citrus wastes & 7,24 & $59,5 \pm 0,4$ & $31,65 \pm 1,11$ & $3,78 \pm 0,26$ & 8,37 \\
Compost $A_{1}$ & Citrus waste and rock phosphate & 7,20 & $45,0 \pm 0,3$ & $22,50 \pm 1,03$ & $2,59 \pm 0,17$ & 8,69 \\
Compost $B_{0}$ & Hulls of cottonseed, ash & 9,55 & $57,5 \pm 1,1$ & $28,79 \pm 1,03$ & $2,61 \pm 0,11$ & 11,03 \\
Compost $B_{1}$ & Hulls of cotton seed, & 9,47 & $48,5 \pm 1,4$ & $24,75 \pm 1,01$ & $2,07 \pm 0,13$ & 11,96 \\
& ash and phosphate rock & & & & & \\
Compost $C_{0}$ & Sheanut cake & 6,52 & $75,5 \pm 1,6$ & $38,55 \pm 1,10$ & $4,20 \pm 0,15$ & 9,18 \\
Compost $C_{1}$ & Sheanut cake and phosphate rock & 6,23 & $62,0 \pm 2,5$ & $34,33 \pm 1,35$ & $3,40 \pm 0,32$ & 10,10 \\
\hline
\end{tabular}

Notes: OM: organic matter; TOC: total organic carbon; NTK: total nitrogen; C/N: carbon/nitrogen 
$(\mathrm{HCl})$ in the presence of phenophthalein 6 . A control (white) is obtained by carrying out the experiment without adding soil in the corresponding container. The difference in the values observed between each of the treatments (soil-compost mixture) and the control (soil without compost) is considered as the amount of $\mathrm{CO}_{2}$ coming from the compost.

The kinetics of carbon mineralization $\mathrm{C}-\mathrm{CO}_{2}$ (t) are adjusted according to the one-compartment model described by the relation?

$\mathrm{C}-\mathrm{CO}_{2}(\mathrm{t})=\mathrm{C}_{0} \cdot\left(1-\mathrm{e}^{-\mathrm{bt}}\right)$

Where: $\mathrm{C}_{0}=$ fraction of mineralizable organic carbon.

$\mathrm{t}=$ incubation time in a day.

$b=$ coefficient of mineralization rate of organic carbon per day.

\section{RESULTS AND DISCUSSION}

\section{Results}

The cumulative $\mathrm{CO}_{2}$ released during the incubation of soil-compost mixtures (100:1) in the laboratory for 75 days is shown on Fig. 1 and the percentage of mineralized carbon from composts on Fig. 2. Kinetics of mineralization during the incubation is adjusted according to the equation (E1). The parameters of these adjustments are shown in Table 3 and Table 4 . The correlation coefficients $\mathrm{R}^{2}$ between the observed and adjusted values are between 0.947 and 0.998 , thus attesting the quality of the adjustments.

The amount of carbon contained in the control, soil without compost, is $148.7 \mathrm{mg}$. Soil-compost treatments at the dose of $0.25 \mathrm{~g}$ of compost (dry) for $25 \mathrm{~g}$ of soil (dry) correspond to an exogenous supply of $79.125 \mathrm{mg}$ of carbon for the mixture Soil + A0; $56.25 \mathrm{mg}$ for Soil + A1; $71.975 \mathrm{mg}$ for Soil + B0; $61.875 \mathrm{mg}$ for Soil + B1; $96.375 \mathrm{mg}$ for Soil $+\mathrm{CO}$ and $85.825 \mathrm{mg}$ for Soil $+\mathrm{C}_{1}$, according to the values in Table 1.

From Fig.1, the soil-compost mixtures respectively released during 75 days of incubation 19.96; 15.96; 27.52; 25.66; 23.72 and $24.26 \mathrm{mg}$ of $\mathrm{C}-\mathrm{CO}_{2}$, versus $4.89 \mathrm{mg}$ for the control without compost; which corresponds respectively to 8.76 ;

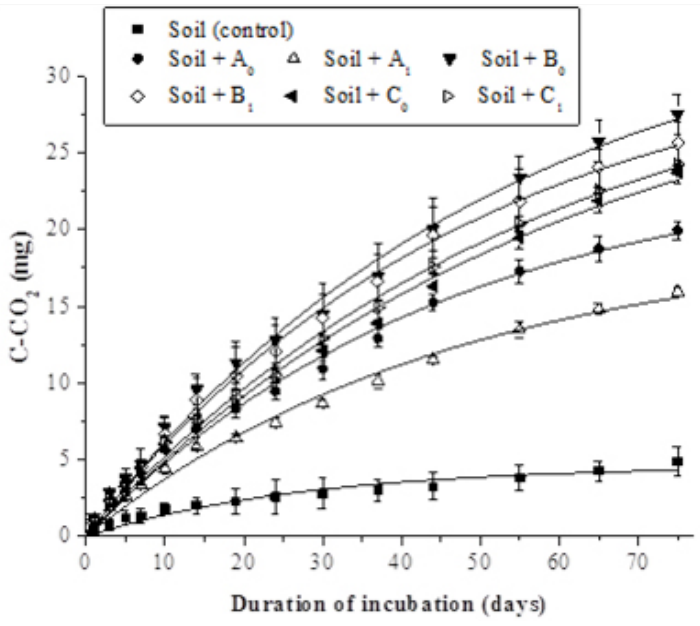

Fig. 1. Cumulative emission of $\mathrm{CO}_{2}$ during incubation of soil-composts mixture

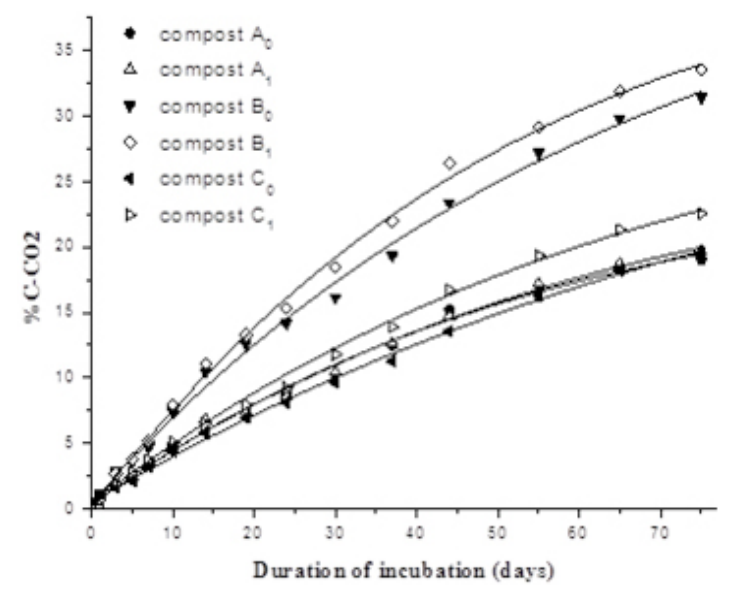

Fig. 2. Percentage of composts carbon mineralized during incubation

Table 3: Adjustment parameters according to $\mathrm{C}-\mathrm{CO}_{2}(\mathrm{t})=\mathrm{Co}\left(1-\mathrm{e}^{-\mathrm{bt}}\right)$ model of the cumulative amount of mineralized carbon $(\mathrm{mg})$

\begin{tabular}{lccc}
\hline Sample & Co & $b$ & $R^{2}$ \\
\hline Soil (witness) & 4.614 & 0.036 & 0.947 \\
Soil + A $_{0}$ & 24.563 & 0.022 & 0.994 \\
Soil + $A_{1}$ & 19.453 & 0.021 & 0.991 \\
Soil + B & 35.860 & 0.019 & 0.994 \\
Soil + B & 32.519 & 0.020 & 0.997 \\
Soil + $C_{0}$ & 32.891 & 0.016 & 0.992 \\
Soil + $C_{1}$ & 33.440 & 0.017 & 0.995 \\
\hline
\end{tabular}

Note Co $=$ potentially mineralizable carbon $(\mathrm{mg})$,

$\mathrm{b}=$ mineralization rate (per day)

$\mathrm{t}=$ mineralization time (day) 
$7.79 ; 12.47 ; 12.18 ; 9.68$ and $10.34 \%$ TOC of the mineralized mixture versus $3.1 \%$ for the control without compost. A correlation between the fraction of potentially mineralizable carbon or labile carbon and the $\mathrm{C} / \mathrm{N}$ ratio of the composts is shown on Figure 3 .

\section{DISCUSSION}

The mathematical description of the dynamics of soil carbon mineralization under controlled conditions is an essential tool for the characterization of soil organic matter and to understand the evolution of carbon in the soil. The carbon fraction of composts potentially mineralizable varies between 25 and $46 \%$ of TOC and depends on the composts. It means that 54 to $75 \%$ of the TOC, depending on the composts, are refractory to mineralization and can therefore be used to maintain the soil carbon stock for the improvement of its physical properties. Depending on the model of the study and the experimental conditions, after one year, $25.77 \%$ TOC of compost $A_{0}, 27.51 \%$ TOC of compost $A_{1} ; 44.67 \%$ TOC of compost $B_{0}$; $46.00 \%$ TOC of compost $B_{1} ; 31.57 \%$ TOC of the compost $\mathrm{C}_{0}$ and $35.46 \%$ TOC of compost $\mathrm{C}_{1}$ will be mineralized. However, soil texture, climatic conditions and the type of agriculture can influence the carbon mineralization of composts in the soil.

For better interpretation, the percentage of exogenous carbon (from composts) mineralized is calculated and shown on Fig. 2. These percentages are, after 75 days of incubation, respectively 19.05 ; 19.68; 31.44; 33.57; 19.54 and 2.57 for composts $\mathrm{A}_{0}, \mathrm{~A}_{1}, \mathrm{~B}_{0}, \mathrm{~B}_{1}, \mathrm{C}_{0}$ and $\mathrm{C}_{1}$.

The exponential adjustment parameters, in Table 4, shows that composts $B_{0}$ and $B_{1}$ have between 45 and $46 \%$ TOC potentially mineralizable, followed by composts $C_{0}$ and $C_{1}$ ( 31 to $36 \%$ TOC), then composts $A_{0}$ and $A_{1}$ ( 25 to $28 \%$ TOC). It should be noted, like Javier ${ }^{10}$, that the fraction of potentially mineralizable carbon depends on composted waste. The alkaline nature of composts $B_{0}$ and $B_{1}$ would contribute to the high mineralization of their organic matter ${ }^{11}$. Alkaline amendments have been shown to increase the dissolved organic matter content of the soi ${ }^{12,13}$ and to stimulate the activity of soil microorganisms ${ }^{14}$, therefore accelerate the mineralization of organic matter. Composts without natural phosphate $\left(A_{0}, B_{0}, C_{0}\right)$ are more stable than composts with natural phosphate $\left(A_{1}, B_{1}\right.$,
$\mathrm{C}_{1}$ ). Composts with phosphate rock have a slightly higher mineralization rate than composts without phosphate rock. This can be explained by referring to Lompo's works ${ }^{15}$ which showed that phosphate rock in the presence of nitrogen stimulates the activity of microorganism's biomass and therefore stimulates the degradation of organic matter.

The correlation between the fraction of potentially mineralizable carbon or labile carbon and the $\mathrm{C} / \mathrm{N}$ ratio of the composts observed, confirms the $\mathrm{C} / \mathrm{N}$ ratio is a characteristic of the stability of the organic matter ${ }^{16}$.

Composts $A_{0}, A_{1}, B_{0}$ and $B_{1}$ have mineralization rates close to 0.02 per day while those of $\mathrm{C}_{0}$ and $\mathrm{C}_{1}$ composts are barely approach 0.015 per day. This low level rate can probably be justified by the acidity of these composts $(\mathrm{pH}=6.2$ and 6.5$)$ because the acidity reduces the mineralization of the organic matter ${ }^{3,17}$.

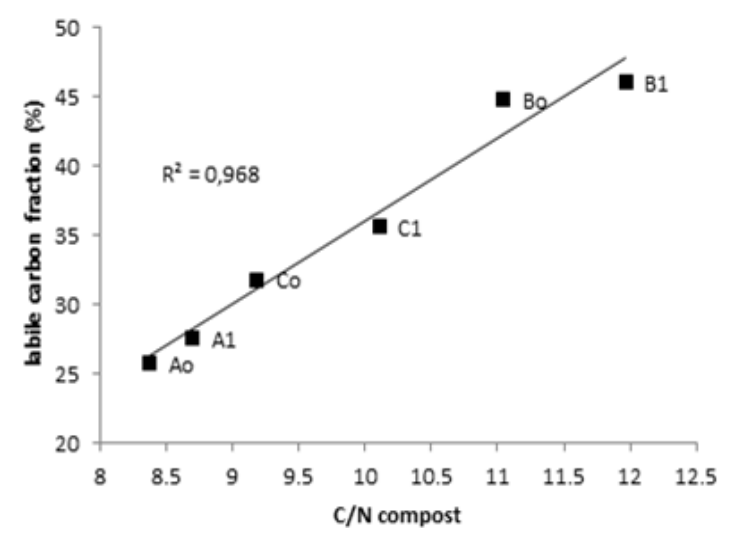

Fig. 3. Correlation between labile carbon and $\mathrm{C} / \mathrm{N}$ ratio

Table 4: Adjustment parameters according to $\mathrm{C}-\mathrm{CO}_{2}(\mathrm{t})=\mathrm{Co}\left(1-\mathrm{e}^{-\mathrm{bt}}\right)$ model of the cumulative amount of mineralized carbon (\%TOC).

\begin{tabular}{cccc}
\hline Compost & Co & $b$ & $\mathrm{R}^{2}$ \\
\hline $\mathrm{A}_{0}$ & 25.800 & 0.019 & 0.996 \\
$\mathrm{~A}_{1}$ & 27.566 & 0.017 & 0.995 \\
$\mathrm{~B}_{0}$ & 44.801 & 0.016 & 0.996 \\
$\mathrm{~B}_{1}$ & 46.064 & 0.018 & 0.998 \\
$\mathrm{C}_{0}$ & 31.846 & 0.013 & 0.996 \\
$\mathrm{C}_{1}$ & 35.677 & 0.014 & 0.997 \\
\hline
\end{tabular}

Notes: $\mathrm{Co}=$ potentially mineralizable carbon fraction (\% TOC),

$\mathrm{b}=$ mineralization rate (per day)

$\mathrm{t}=$ mineralization time (day) 


\section{CONCLUSION}

According to the experimental conditions of this study, the potentially mineralizable carbon fraction of composts varies between 25 and $46 \%$ of the total organic carbon; which means that 54 to $75 \%$ of the carbon is refractory to mineralization and can therefore be used to maintain the soil carbon stock in order to improve its physical properties. This mineralization is correlated with the $\mathrm{C} / \mathrm{N}$ ratio of the composts and fast when the compost is alkaline.

However, soil texture, climatic conditions and the type of agriculture have an effect on the mineralization of carbon in the soil.

\section{ACKNOWLEDGMENT}

This work was fully supported by " Laboratoire de Gestion, Traitement et Valorisation des Déchets " and "Laboratoire de Chimie Atmosphérique ", two labs of the Faculty of Sciences of the University of Lomé. Authors are very grateful to Professor Gado TCHANGBEDJI, Dean of Faculty of Science for his support and improvement of this manuscript.

\section{REFERENCES}

1. Tamara C.F., Daniel V. M. J. Environ. Qual., 2006, 35, 183-193.

2. Tandy S., Healey J.R., Nason M.A.,Williamson J.C., Jones D.L. Environ Pollut., 2009, 157, 690-697.

3. Huang C.-C., Chen Z.-S. Soil Science and Plant Nutrition., 2009, 55, 715-724.

4. Cambardella C.A., Richard T.L., Russel A. European Journal of Soil Biology., 2003, 39, 117-127.

5. Qayyum M.F., Liaquat F., Rehman R. A., Gul M., Hye M.Z., Rizwan M., Rehaman M.Z. Environ. Sci. Pollut. Res., 2007, 24, 26060-26068.

6. Pedra F., Polo A., Ribeiro A., Domingues H. Soil Biology \& Biochemistry., 2007, 39, 1375-1382.

7. Annabi M., Bahri H. and Latiri K., Biotechnol. Agron. Soc. Environ., 2009, 13 (3), 401-408.

8. Tchegueni S., Kili K. A., Bodjona M.B., Koriko M., Hafidi M., Baba G., Tchangbedji G. Int. J. Biol. Chem. Sci., 2012, 6(3), 1381-1389.
9. Som M.-P., Thèse de Doctorat Université de Poitiers, France., 2006.

10. Javier D.S., Thèse de Doctorat, INP-Toutouse, France., 2005.

11. Kalbitz F., Solinger S., Park J.H., Michalzik B., Matzner E., Soil Science., 2000, 165 (4), 277-304.

12. Grybos M., Davranche., Gruau G., Petitjean P., Pédrot M., Geoderma., 2009, 154 (1-2), 13-19.

13. Li Z.P., Han C.W., Han F.X., Geoderma., 2010, 157, (3-4), 206-213.

14. Xue D., Huang X., Yao H., Huang C., Journal of Environmental Sciences., 2010, 22(8), 1253-1260.

15. Lompo F., Segda Z., Gnankambary Z., Ouandaogo N., Tropicultura., 2009, 27(2), 105-109.

16. Bernal M.P., Alburquerque J.A., Moral R., Bioresource Technology., 2009, 100, 5444-5453.

17. Fabre B., Kockmann F., Fourrages., 2006, 185, 103-122. 